\title{
Comparative Study of the Political View of Abdur-Rahman Al-Kawakibi and Shakib Arsalan
}

\author{
Abdi 0. Shuriye \\ Mosud T. Ajala \\ Engineering, Kulliyyah of Engineering, International Islamic University, Malaysia \\ P.O. Box 10, 50728 Kuala Lumpur, Malaysia \\ shuriye@hotmail.com; mosud.ajala@yahoo.com \\ Department of Mechatronics Engineering, Kulliyyah of Engineering, International Islamic University, Malaysia \\ P.O. Box 10, 50728 Kuala Lumpur, Malaysia \\ E-mail:mosud.ajala@yahoo.com
}

\section{Doi:10.5901/jesr.2014.v4n6p539}

\begin{abstract}
Both al-Kawakibi and Arsalan lived in late nineteenth century characterised with decline of the Muslim nations and the British, French and Italian imperialism. Muslims became promoters of the imperialist cause and Muslim elites were separating religion from politics an idea en route to secularism. The state of Muslims during this period was same everywhere, though varies in degree. Muslims lag far behind in almost everything. Al-Kawakibi and Arsalan rose to identify the causes of the decline of the Muslim ummah as majorly an internal factor than external. Similarly they promoted the return to Al-Qur'an and fundamental principles of Islam, and further advocated Knowledge for all, without dichotomy between religion and science.
\end{abstract}

\section{Introduction}

Evidently Muslims in the past were recognized with the leadership of the world. They reigned and acquired fame and name for about nine centuries. Through Islam the disunity among them before the advent of Islam was replaced with unity, barbarism with civilization, hard-heartedness with mutual love and sympathy, paganism with worship of one God. With this dynamism they became leaders of half the world in the short span of half a century, this started "towards the close of the Uthman's caliphate and during the caliphate of Ali no power on earth could have prevented them from conquering the whole world" (Shakib Arsalan, 1944). These are all as a result of new life imparted by the Holy Qur'an.

Contrary to what was achieved then, Muslims of other generations are deep down into degradation, little or nothing is left in those virtues to which they garner all their successes. It becomes a shadow of Iman, a rotten skeleton of Islam, an empty name without lifelines in accordance with the instructions of the Quran. With critical inquiry, it was discovered that larger part of the motivating power that accounted for their victories and achievements has disappeared although vestiges of it are still visible here and there like the fading lines of a tattooed hand.

This resulted to the period described as the peak period of British, French and Italian imperialism in which many Muslim nations were turned to be subjects of European countries. Muslims became familiar with ideas of the imperialist and promote their cause. They became aware of the might and strength of the West as well as their evils. Their values were growing into westernized and traditional sphere of influence, while the Muslim elites were separating religion from politics an idea en route to secularism. The state of the Muslims during this period in terms squalor was same everywhere, though varies in degree. Muslims lag far behind in almost everything. According to Shakib Arsalan (1944) "though there are awakening in matters of spiritual, but the "forward movement of the Muslims has not advanced anywhere to come near the nations of Europe, America or Japan". Amongst the malady of the day was the tyrannical system of government that was ascribed to the custodian of caliphate the Ottoman Turks, immorality, the birth of conservatives and ultra-modern Muslims, the assumed incompatibility between religion and science etc.

To salvage the stagnation of the Muslims, a few thinkers and activists were engrossed with dissecting the problems and proffering solutions to these conditions. Dr Qaradawiy wrote about the emergence of reformers:

"The issue (of the comprehensiveness of Islam), which is denied and rejected by the modernists, secularists, and Marxists in an overall sense, is an idea agreed upon by all Islamic scholars. We have seen the Islamic reformers in the modern era, beginning with Ibn 'Abd-al-Wahhab, al-Mahdi, Khayr al-Din al-Tunsi, al-Sanusi, Prince 'Abd-al-Qadir, 
Jamal al-Din al-Afghani, then up through al-Kawakibi, Muhammad 'Abduh, ShakibArslan, Rashid Rida, Hassan alBanna in Egypt, IbnBadis and his brothers in Algeria, 'Allal al-Fassi in Morocco, al-Mawdudi in Pakistan, and others. All of them embraced the comprehensiveness of Islam in doctrine and law, da'wa and the state, and religion and politics. They were not satisfied with merely reporting this in theory, but instead they plunged right into the hardships of putting politics into practice, and faced its risks and troubles, and suffered its trials and afflictions" (Yusuf al-Qaradawi, n.d.)

He explained that all of them strove to put into practice the comprehensiveness of Islam, for three reasons: first, the comprehensiveness of the doctrine of Islam; second, Islam rejects the partitioning of its rulings; and third, life is an indivisible and inseparable unit, and so is man.

Hence, this study evaluates the efforts Shakib Arsalan who implemented his reform working within the existing order "the Ottoman state" and Abdur-Rahman Al-Kawakibi who implemented his own reform outside the Ottoman state.

\section{The Environment}

\subsection{Al-Kawakibi and his Environment}

He was one of the innovators of the Arab awakening who lived in the second half of the $19^{\text {th }}$ century characterized by the decline of Ottoman Empire and colonization of the Muslims nation by the Europeans. Alaa Bayoumi (n.d.) described Kawakibi as thus: "Abdul Rahman Al-Kawakibi (1854-1902), was considered to be one of the main founders of Arab nationalism". Raz (1996) affirms: "Abd al-Rahman al-Kawakibi occupies a unique place among the intellectuals of the Nahda - the Arab revival".Rahme(1999) stated: "The second half of the nineteenth century witnessed an acceleration of the rate of change within the Ottoman empire along with a greater interconnectedness with Europe, its peoples, technologies, and ideas. Namik Kemal, Muhammad 'Abduh, and Jamal al-Din al-Afghanl were among the early thinkers who absorbed the new ideas emanating from Europe and transformed them into an Islamic idiom. Their reformist ideas found an echo among various constituencies and intellectual traditions. 'Abduh's emphasis on internal reform, especially on the reform of education, was appropriated by one of his numerous disciples, 'Abd al-Rahman al-Kawakibl (18541902)"

Funatsu(2006) argues about the period and the events around that time "al-kawakibi's lifetime, the second half of the nineteenth century, marked the continued decline of Ottoman era and growing European ascendance. Most of the Ottoman Empire, including its Arab provinces, was in a state of stagnation and under the rule of venal and corrupt Ottoman officials. Nevertheless, there was a general recognition of the importance of Islam as the primary bond between Arabs and Ottomans. It was a bond nourished by Sultan Abdul Hamid II's (r. 1876-1909), emphasis of the importance of his role, however is questionable, as caliph and protector of Islam".

Based on the events in his environment, kawakibi wanted the regeneration of both the Islamic world and the Arab world, and he regarded the two as symbiotic. He suggested a collective Arab identity under Arabism, according to ref 6 with this idea "he became the first Arab thinker to develop the modern concept of 'Arabness"'(Funatsu, 2006). He held the concept of Arab nationalism that is all-inclusive which made his reformist mission to include believers of other faiths. This created an opportunity for Muslim Arabs to oppose Ottoman rule. He called for separation of religion from state.Funatsu(2006)wrote: "The separation of temporal and religious authority is also a central theme of al-kawakibi's discussion of the ideal polity". He was portrayed as Pan Arabsism developing an Arab independent identity, as Pan Islamist, as a revolutionist, an advocate of Socialism, an Islamist, a Secularist and a Pragmatic thinker(Funatsu, 2006).

\subsection{Arsalan and his Environment}

Shakib Arsalan, "a gentleman of the Arab-Ottoman", "an advocate of Islamic Nationalism" and "a mentor of a generation" (Cleveland, 1985) was born and lived in the late nineteen century, though Al-kwakibi was born before him and by Allah's design kawakibi left the world before him. His period too was characterised as stagnation of Muslim nations, domination of the Europe and the contending separation of Arab from the Turks. His name is written as Shakib Arslan by some authors. The work of Cleveland (1985) shows the relationship between Arsalan and the then head of Ottoman state, sultan Abdulhamid. Cleveland (1985) wrote in his book: "The crystallization of Arslan's political and social views occurred during the latter part of Abdulhamid's reign. He was in perfect accord with his sultan-caliph and forever regretted the passing of his office and the dismantling of his empire". The work also identified the common interest of Abdulhamid and Arslan; Unity of Islam and the prevailing conditions of the muslim states. He continues: "Like Abdulhamid, Arslan saw that the Islamic territories over which the Ottoman Empire exercised political authority were in danger of being isolated 
and occupied by the Western imperial powers just as Algeria, Tunisia, and Egypt had been. To prevent this occurrence, the Ottoman state needed to be strengthened. This did not imply the wholesale adoption of European concepts of state and society. On the contrary, it meant a regeneration of Islam, a reassertion of Islamic solidarity, and a reinforcement of the office of caliph".

The same work described Arsalan as pro-Ottoman who believe in the survival of Ottoman caliphacy rather than Arab Nationalism. He argues: "Arslan had been educated during the nahdah, but remained untouched by the sentiments of Arab separatism it sparked in others; he had visited the Paris of the Third Republic and the London of Gladstone, but found no attraction in the doctrines of European liberalism; he knew prestige as a Druze, but committed his political future to the survival of the Ottoman call him". Kramer affirms: "As the nineteenth century closed, Arslan chose as his vocation the defence of all Islam, becoming a fiercely patriotic Ottoman and a cosmopolitan pan-Islamist".

Ryad (2011)described the influence of Arsalan in the Moroccan history thus: "The anticolonial reformist activism of the Druze Prince Shakıb Arslan (1871-1946) was one of the most important impulses that nurtured the thoughts of many Moroccan leaders. In his political career Arslan moved from Ottomanism to Arabism and ended as a sincere advocate of Islamic nationalism.

He held an opposing view to the cessation between the Arabs and the Turks (Amir Shakib Arsalan, 2004). Cleveland (1985) also noted: "His message was just simply 'a divided Empire would fall to Europe'". During one of his tour of the Arab capitals for Ottoman-Islamic solidarity he said (as cited in Cleveland, 1985): "I spoke of the inappropriateness of the split between Arabs and Turks and of the necessity to adhere to the Empire. I warned about the policy of foreigners who wanted to suggest there were difficulties between Arabs and Turks in order to exploit them to their own advantage, take over the Ottoman territories, and turn them into colonies". He argued that the difference between Arabs and Turks were superficial or created by the imperialist manipulations.

\section{Audience}

Al-kawakibi's audience were the literates, intellectuals, and the Muslims in his society.(Alaa Bayoumi, 2005)wrote about Al-kawakibi's audience: "in this regard, it is important to note that Kawakibi did not speak to multiple audiences. All his writings were written in the Arabic language and were directed toward an Arab audience. It is also important to note that Kawakibi's discourse was a little bit too sophisticated for the regular Arab and Muslim masses, which were largely uneducated at his time. Therefore, one can say that Kawakibi's main audience were the educated Arab and Muslim sections of his society". Funatsu(2006) described his audience as thus: "Kawakibi did not write for multiple audiences. His style was too sophisticated to be accessible to the Arab masses, few of whom were literate. Instead, he spoke primarily to the educated social stratum, a constituency of intellectuals he aimed to inspire to work toward reform".

\section{Views and Advocacies}

\subsection{Causes of Decline}

Al-kawakibi in his analysis of the state of the Muslims believes that the factors that led to decline of the Muslims are more of internal than external. These internal factors were identified to be seventy seven. Twenty eight are classified as fundamental causes and forty nine were derived from the fundamental causes. All these causes are grouped into religious, political, moral and miscellaneous causes. Tahan (as cited in Alaa Bayoumi, 2005) argues: "He believed that the decline of Muslims arose from three main internal problems that had many roots and manifestations: misunderstanding of the Islamic religion by the Muslim scholars and masses, the political tyranny of Muslim rulers, and the corruption of the ethics of his contemporary Muslim masses". And in the workLouai (2009), he wrote that: "His book... a pseudo-conference among twenty-two representatives from many part of the Muslim world that came to identify the reasons behind the backwardness in the Islamic world and its remedies. Thus he underlined that the reasons are political, religious and behavioural". In Rahme (1999),Ottoman political and administrative style, and miscellaneous causes (which include incongruity of the rulers and the ruled, weakness in character, neglect of women education and thoughtlessness) were added as other factors that led to the decay of the Muslim nations.

Arsalan also shared the same opinion when he argues: "The change occurred in Muslims themselves". He cited:

For each one, are successive [angels] before and behind him who protect him by the decree of Allah? Indeed, Allah will not change the condition of a people until they change what is in themselves. And when Allah intends for a people ill, there is no repelling it. And there is not for them besides Him any patron. (Al-Qur'an, ar-Ra'd:11) 
Arsalan continues: "It would therefore have been a matter for wonder and astonishment if even after the Muslims had changed their course and condition, God forborn to alter their affairs and in place of their earlier greatness and honour He had not brought degradation and dishonour upon them"(Shakib Arsalan, 1944).

\subsection{Ignorance and Knowledge}

In Funatsu (2006) ignorance was identified as the origin of the Muslim inaction according to Kawakibi. He asserted that the worst of ignorance is the religious ignorance. He proposed that the learned in the society should take up the responsibility of leading the reform by making the common people "sense the agony of despotism." He emphasised on knowledge and education as the antidote to ignorance through which despotism develops.

Arsalan understood ignorance as the leading cause of Muslims stagnation. In his work Causes of Our decline he stated: "One of the chief causes of the downfall of the Muslims is their stack ignorance; due to ignorance they are unable to distinguish between wine and vinegar; hawk and a hand-saw". He identified inadequate knowledge as another cause of inactivity. He viewed partial knowledge as more dangerous than ignorance itself. He argued that possessor of inadequate knowledge while he is incapable of understanding correctly, refuses to acknowledge his own incapacity. Following the general adage of "full lunacy is better than semi-lunacy", he concluded that ignorant man is better than one possessing a "little knowledge". He therefore proposed ato return the fundamentals of Islam that is nurtured by the Quran (Amir Shakib Arsalan, 1944)

\subsection{Weakness in Character}

Al-Kawakibi observed weakness of Morals as one of the causes on decline. According to Rahme (1999) "weakness of character" was mentioned as the fourth problem under miscellaneous factors according to kawakibi. He said: "the fourth and last factor was 'the weakness of character', which is, the decline in determination'. He concluded that the shocking consequence of this decline is their judgement that perfection belongs to foreigners. Kawakibi wrote:

"This infatuation with the foreigners had led Muslims to imitate them blindly and follow them in matters that they considered refined and elegant, without their realizing that they were being deceived. Among such pernicious practices were the abandonment of one's pride in one's religion, praying in isolated places, the neglect of popular customs, such as the wearing of the turban, and other 'lowly habits. These practices had been adopted by the rising generation, which could best be described, according to al-Kawakibi as 'without morals"' (Funatsu, 2006)

Arsalan believed that "immorality" of the Muslims is another origin of degeneration. He argued that the decent qualities which the Muslims were known with in the early days of Islam are in the decrease. He said: "Gone are the strength of character and all other virtues. In so far as the conditions leading to the well-fare, progress and decline of nations are concerned, character has a higher place than all the wealth of learning and knowledge" (Amir Shakib Arsalan, 1944). He used the poem of Ahmad Shawqi - "Nations are only as long as their character remains. When their character vanishes, they also disappear- to buttress his point" (Amir Shakib Arsalan, 1944).

\subsection{Cowardice and Frenzied panic.}

According to Kawakibi, cowardice that is classified among the factors of Moral causes (interpreted as the behavioural causes by some researchers and as ethics of the Muslim masses by others) is one of the causes of Muslims decadence. He identified that people fail to agiate for their rights due to "cowardice and fear".Louai(2009) wrote: "The behavioural reasons' of decline include: "...the widespread ignorance and lack of education, laziness and pessimistic thinking, the lack of coherent educational and adequate financial system, the absence of good citizenry and the will to fight for what's right due to fear and cowardice". Alaa Bayoumi (2005) also inform: "...Kawakibi criticize of the ethical and moral status of his contemporary Muslims. He criticized them for being used to ignorance and for being hopeless. Also accused them of being lazy, of becoming disinterested in advising or helping each other, and of being unwilling to stand up and fight for their freedoms and rights".

The description of Muslims in terms of bravery and strength is given as thus:

"O Prophet, urge the believers to battle. If there are among you twenty [who are] steadfast, they will overcome two hundred. And if there are among you one hundred [who are] steadfast, they will overcome a thousand of those who 
have disbelieved because they are a people who do not understand. Now, Allah has lightened [the hardship] for you, and He knows that among you is weakness. So if there are from you one hundred [who are] steadfast, they will overcome two hundred. And if there are among you a thousand, they will overcome two thousand by permission of Allah. And Allah is with the steadfast" (Al-Qur'an, al-Anfal:65-66)

However Arsalan observe lack of courage among the Muslims. He argued: "those who were respected for their death-defying courage have become mere coward and poltroons because of falling victim of cowardice". Due to this, the Islamic spirit of bravery is void in the hearts of many Muslims and the vacuum created gave way to fear and panic to fill their hearts. He identified despair from compassion and mercy of Allah as a factor that resulted into the "frenzied panic" that has taken possession of the Muslims. He observes that: "There seems to be deep-rooted feeling in many Muslim hearts that in any case victory is for the Europeans, that they are invincible and that all resistance is futile". The Druze of eloquence reminded the Muslims as thus:

And do not weaken in pursuit of the enemy, If you should be suffering - so are they suffering as you are suffering, but you expect from Allah that which they expect not. And Allah is ever knowing and Wise (Al-Qur'an, an-Nisail: 104)

He argues that the result of the cowardice attitude of the Muslims will only result to famines and economic depression he wrote: "... weaker nations never enjoy any freedom in trade or other economic pursuit. Their enemies who hold dominion over them exploit all that is profitable and pleasurable in their own country and throw out only the remnants of useless skins and bones for the locals tolick and suck at. Thus the countries of the weaker nations very often fall prey of famines and economic depressions and thousands die of hunger"(Shakib Arsalan, 1944)

Another problem attached to this is the seeking after wealth of the Muslims and perception that wealth is above other things. With this believe Muslims ran after life which made their affection for life grow stronger and in contrary they lost the life itself. Hence Arsalan identified cowardice and avarice as the root causes of the emasculation of Muslims today (Shakib Arsalan, 1944).

\subsection{Incompatibility of Religion with Science}

Al-Kawakibi identified "Belief that the philosophical and rational sciences are incompatible with religion" and "Enmity towards Higher sciences because of the comfort of ignorance and abasement" as two fundamental factors of degeneration in this regard. He believe the notion was so prevalent that it created abandonment of litihād - the exercise of independent reasoning, passive imitation -taqlïd, the introduction of innovations, heresies and superstitions (Rahme, 1999). On these factors Louai(2009)wrote: "... the broad interpretation of the Koran and the Sunna, the ignorance of the religious clerics who are prone to issue wrong ruling and make people believe that religion reject science and rational thinking...".This idea of Al-kwakibi led to his advocacy for "right to exercise one's own reason" and "the use of the controversial method of talfiqq, the selection of rulings from different schools of jurisprudence according to the dictates of individual conscience" (Funatsu, 2006).

Arsalan however, presented his view of how the notion of incompatibility between religion and science have been a cause of inactivity by identifying two classes of muslims whose characters are dangerous to the growth of Islam. He identified them as the "Incorrigible Conservatism" and the "Ultra- modernist". The latter he believed are more dangerous to Islam because of their view that Muslims will not get any progress as long as they followed Islam. And the former are not harmful because they act on ignorance and blind dogmatism which resulted into belief that Islam is responsible for the decline and fall of the Muslims. Their words and acts led people to the conclusion that Islam is only concerned about the affairs of the life after. While on the contrary Arsalan admonished with words of Al-quran: "But seek, through that which Allah has given you, the home of the Hereafter; and [yet], do not forget your share of the world. And do good as Allah has done good to you. And desire not corruption in the land. Indeed, Allah does not like corrupters"(Al-Qur'an, alQasas:77). He explained that Islam is concerned about the two worlds - here and hereafter, and argues that the dependency of the Muslims on their enemies is due to the unresponsiveness of the conservatives to science. This in turn made the enemies believe that Islam nurture 'idleness and inactivity' and that it 'not only conflict with modern civilization but even deprive its followers of the latter's benefits'.

\subsection{Tyranny and Despotism}

Al-Kawākibī regarded the "Ottoman political hegemony" as one of the causes of the weakening of Islamic communities. 
He highlighted that the ottoman political system lacked shurah mechanism, stable and harmonious body of laws. He accused the system of delegating power to oppressive rulers and the imposition of a "single administrative and criminal legal code". He defines political despotism according to al-Husri (as cited in Funatsu, 2006) as an "attribute of the absolute government that conducts the affairs of its subjects wilfully and arbitrarily, with no fear of accountability or punishment." He was also against any impression that depicts Islam as being despotic. This is because he believed Islamoffered the people a pathway to live under liberty and freedom and if there were errors the representative of that religion should be blamed and not the religion. He asserted: "... It was not the religion that was to be blamed but its appropriation by religious and political despots. Islam provided the foundations of a political and social order that combined "the best of democracy and aristocracy"(Funatsu, 2006)

Arsalan identified the Muslim aristocrats as a factor of decadence during his x-ray of the factors responsible for the decadence of the Muslim nations. He expatiates by describing the principles held by the aristocrats which says that they can do and undo and that masses are created to serve their interest. He said: "this thought is so deep rooted in them that if anyone tried to wean them from it, they feel no scruples in terrorising him into abject submission to serve as an object of lesson for other" (Amir Shakib Arsalan, 1944). He also noted the activities of some learned who backed these despotic leaders by passing death judgement upon any courageous individual who dare tries to correct this rulers or declaring such individual as a rebel. He observed that the learned men have role of preventing the leaders from their erring ways and guiding the caliph and his subordinates from sinful living. He however belief that today's learned men have derailed. They have made their knowledge a source of revenue and religion a bat used for hunting worldly pleasures. In his words he said: "they made no scruples to sanction the wickedness and barbarous cruelties of despotic rulers and pave the way for the violation of religion itself". He concluded that the result of this was deceit; common men were deceived by the appearance of this knowledgeable and their titles believing in whatever verdict they passed in religious affairs. The resultant effect of this is the growth in enmity, mischief, departure of common weal, hatred and harshness.

\section{Remedies}

Kawakibi championed the theory of science complement religion as a remedy to the decline of the Muslim nations, (Louai, 2009) affirm: "Alkawakibi went on to say that the essential and adequate remedies to all these ills are religion and science, as he believed that religion and science add and complement each other. Therefore, in his views, the Muslims should use their religion to understand the role of science and profit from it in their lives". Tahan (as cited in Alaa Bayoumi, 2005)affirmed that Kawakibi supported the idea of gradual change, he wrote: "Tyranny, Kawakibi thought, cannot be resisted by force, but it can be resisted by soft power and gradualism". He also propounded that Muslims should make effort to create an alternative leadership and political schemes that would be devoid of tyranny. Ref 3 Kawakibi promoted the idea of establishing a civil society similar to that of the Europeans. This, he thought will strengthen Muslim civil societies (Alaa Bayoumi, 2005). He promoted creation of a structure for constitutional consultation (shūrādustūriyya) and the establishment of communicating avenues to the population about the objectives and direction of reform as in ref 6 . He also required that the Arabs should be among the forerunners of spreading the reform agenda. Describing why he chose the Arabs he said: the glories of Islam were Arab contributions; they possess distinctive virtues of solidarity, courage, loyalty, generosity, and resilience, consultation in public affairs, practitioners of the purest form of Islam. They were respectful of the principles of democratic exchange and equal rights. They fiercely guarded their liberty and independence and were least accepting of authoritarianism.

Arsalan proposed that the Quran teachings should be given his due place in reawakening because lack of these teachings may make the nations fall prey of atheism and to a life of licence and immorality. Hence he advocates for combination of religious training and the 'purely worldly knowledge'. He suggested that recourse to Qur'an and taking inspiration from it can lead the Muslims to the level they aspired for in knowledge of science and in making progress. This will, can make the Muslims more qualified for progress than others(Amir Shakib Arsalan, 2004). He concludes:

Therefore let us shake off our despair; let us take a step forward; let us sacrifice everything. Keep steady our ambitions. With constant discipline, with will and determination to march onward and with correct understanding of the essentials of iman taught by the quran, let us strive and continue to strive. Know that if we do so our hopes and aspirations will soon be realised. 'And those who strive for Us - We will surely guide them to Our ways. And indeed, Allah is with the doers of good' (Al-Qur'an, al-Ankabut:69)

Other solutions he suggested include moral and material Reformation of the Lands, following examples of the developed nations and the spirit of sacrificing both wealth and self. (Amir Shakib Arsalan, 2004) 


\section{Conclusion}

Abdur-Rahman al-Kawakibi and Shakib Arsalan were among the few thinkers and Muslim activists who analysed the factors that caused the stagnation of the Muslim world and suggested solutions to these problems. Both, form different perspectives, identified that the causes are more of internal than external. Arsalan during the Ottoman reign implemented his reform agenda working within the Ottoman state campaigning unification of all Muslims. On the other side Al-kawakibi worked from outside the Ottoman state promoting the idea of Arab Nationalism. Both presented their reforms through academic works.

\section{References}

Alaa Bayoumi. (2005). The Occidental Discourse of Abdul Al-Rahman Al-Kawakibi. Alaa Bayoumi. Retrieved November 02, 2013, from http://alaabayoumi.blogspot.com/2005/11/chapter-5-occidental-discourse-of.html

Shakib Arsalan. (1944). Our Decline and Its Causes (p. 135). Sh Muhammad Ashraf, Lahore, Pakistan.

Shakib Arsalan. (2004). Our Decline, Its Causes and Remedies (p. 148). Islamic Book Trust, Kuala Lumpur, Malaysia.

Cleveland, W. L. (1985). Islam Against the West: Shakib Arslan and the Campaign for Islamic Nationalism (pp. 1 - 223). Unievrsity Texas of Press, Austin.

Funatsu, R. (2006). Al-Kawākibī 's Thesis and its Echoes in the Arab World Today. Havard Middle eastern and Islamic Review, 7, 1-40. Louai, C. (2009). Clash of Thoughts Within the Contemporary Arab Discourse. University of Central Florida.

Rahme, J. G. (1999). "Abd al-Rahman Al-Kawakibi"s Reformist Ideology, Arab Pan-Islamism, and the Internal Other. Journal of Islamic studies, 10(2), 159-177.

Raz, R. (1996). Interpretations of Kawakibi 's thought , 1950-1980s. Middle Eastern Studies, 32(1), $179-190$.

Ryad, U. (2011). New episodes in Moroccan nationalism under colonial role : reconsideration of Shakib Arslan's centrality in light of unpublished materials. The Journal of North African. Retrieved December 16, 2013, from https://www.academia.edu/3099078 INew_episodes_in_Moroccan_nationalism_under_colonial_role_reconsideration_of_Shakib_Arslans_centrality_in_light_of_unpu blished_materials

Yusuf al-Qaradawi. (n.d.). "The Islamic Shari ' ah Governs All of the Actions" of Muslims. Translating Jihad. Retrieved December 10, 2013, from http://www.translatingjihad.com/2011/03/yusuf-al-garadawi-islamic-shariah.html 